University of Nebraska - Lincoln

DigitalCommons@University of Nebraska - Lincoln

\title{
Quantifying the Effects of Small-Scale Heterogeneities on Flow and Transport in Undisturbed Cores from the Hanford Formation
}

\author{
M. N. Pace \\ Oak Ridge National Laboratory, pacem@ornl.gov
}

M. A. Mayes

Oak Ridge National Laboratory

P. M. Jardine

Oak Ridge National Laboratory

T. L. Mehlhorn

Oak Ridge National Laboratory

John M. Zachara

Pacific Northwest National Laboratory, john.zachara@pnl.gov

See next page for additional authors

Follow this and additional works at: https://digitalcommons.unl.edu/usdoepub

Part of the Bioresource and Agricultural Engineering Commons

Pace, M. N.; Mayes, M. A.; Jardine, P. M.; Mehlhorn, T. L.; Zachara, John M.; and Bjornstad, B.N., "Quantifying the Effects of Small-Scale Heterogeneities on Flow and Transport in Undisturbed Cores from the Hanford Formation" (2003). US Department of Energy Publications. 299.

https://digitalcommons.unl.edu/usdoepub/299

This Article is brought to you for free and open access by the U.S. Department of Energy at DigitalCommons@University of Nebraska - Lincoln. It has been accepted for inclusion in US Department of Energy Publications by an authorized administrator of DigitalCommons@University of Nebraska - Lincoln. 


\section{Authors}

M. N. Pace, M. A. Mayes, P. M. Jardine, T. L. Mehlhorn, John M. Zachara, and B.N. Bjornstad 


\title{
Quantifying the Effects of Small-Scale Heterogeneities on Flow and Transport in Undisturbed Cores from the Hanford Formation
}

\author{
M. N. Pace,* M. A. Mayes, P. M. Jardine, T. L. Mehlhorn, J. M. Zachara, and B. N. Bjornstad
}

\begin{abstract}
Accelerated migration of contaminants in the vadose zone has been observed beneath tank farms at the U.S. Department of Energy's Hanford Reservation, Richland, WA. This paper focuses on quantifying hydrologic processes that control the fate and transport of contaminants in the unsaturated sediments beneath the Hanford tank farms. The experimental approach involved the use of field relevant, longterm unsaturated nonreactive transport experiments in undisturbed sediments from the Hanford Formation. Undisturbed sediment cores were collected from a laminated fine-grained sand unit within the Hanford Formation in both the vertical direction (flow cross bedding) and the horizontal direction (flow bedding parallel). Laboratory-scale saturated and unsaturated flow experiments were conducted using multiple nonreactive tracers to investigate hydrologic processes controlling the vertical and lateral spread of contaminants. The nonreactive tracers differ in their free-water molecular diffusion coefficients, thus providing a quantitative measure of diffusional processes and the presence of immobile water. Asymmetric breakthrough curves (BTCs) and coelution of tracers were observed during saturated flow in both horizontal and vertical cores, indicating advection enhanced solute dispersion with no accompanying immobile water. Unsaturated tracer transport in the vertical and horizontal cores resulted in earlier breakthrough, asymmetric BTCs, and differential breakthrough of tracers where the elution of piperazine-1-4-bis(2-ethanesulfonic acid) (PIPES) preceded that of pentafluorobenzoic acid (PFBA), which preceded that of $\mathrm{Br}^{-}$. These results suggest that physical nonequilibrium processes (PNE) such as preferential finger flow coupled with immobile water may control the unsaturated movement of contaminants in the Hanford Formation.
\end{abstract}

$\mathrm{T}$ HE U.S. Department of Energy's Hanford Reservation is a nuclear materials processing facility located in the Columbia River Basin in south-central Washington. The area receives an average annual rainfall of 16 $\mathrm{cm} \mathrm{yr}^{-1}$. Depth to groundwater averages around $100 \mathrm{~m}$ across the site. The vadose zone is composed of sediments from the Hanford Formation, the Cold Creek Unit, and the Ringold Formation at the groundwater interface. Processing waste has historically been disposed of in cribs, solid waste burial pits, ponds, and/or underground storage tanks within the Hanford Formation. The most concentrated wastes were stored in single-shelled tanks in the 200 Area of the Hanford Site (Bjornstad, 1990; Agnew et al., 1997). About one-third of the tanks in the 200 Area have leaked, resulting in

M.N. Pace, M.A. Mayes, P.M. Jardine, and T.L. Mehlhorn, Environmental Sciences Division, Oak Ridge National Laboratory, P.O. Box 2008, Oak Ridge, TN, 37831-6038; J.M. Zachara and B.N. Bjornstad, Environmental Dynamics and Simulation, Environmental Molecular Sciences Laboratory, Pacific Northwest Laboratory, Richland, WA. Received 15 July 2003. Original Research Paper. *Corresponding author (pacem@ornl.gov).

Published in Vadose Zone Journal 2:664-676 (2003).

(c) Soil Science Society of America

677 S. Segoe Rd., Madison, WI 53711 USA more than 4 million liters of hazardous and radioactive waste in the vadose zone. Relatively mobile radionuclides such as ${ }^{99} \mathrm{Tc},{ }^{129} \mathrm{I}, \mathrm{U}$, and ${ }^{3} \mathrm{H}$ have traveled further than predicted by current models and have been detected in the groundwater, which eventually flows to the Columbia River (Dirkes and Hanf, 1997; Hartman and Dresel, 1997). This suggests the mechanisms of such accelerated contaminant migration remain unclear. It is thought that vertical preferential flow may occur along clastic dikes or uncased well boreholes. Finger flow that results from unstable wetting fronts may also increase the rate of vertical transport in stratified media (Ritsema et al.,1993, 1998; Glass et al., 1988, 1989; Sililo and Tellam, 2000). Variation in hydraulic conductivity caused by differences in grain size may also result in lateral flow and transport along bedding planes (Newman et al., 1998). Further, diffusion into finer-grained media may slow the transport of contaminants and may also act as a source of contamination as clean water is transported through the formation. An enhanced conceptual understanding of the influence of physical heterogeneities within the Hanford Formation (e.g., variations in grain size, lithologic stratification, and discontinuities) on contaminant mobility is essential for accurate prediction of flow and transport processes beneath the tank farms.

The effects of physical heterogeneities in undisturbed media on contaminant flow and transport may be quantified by performing miscible displacement experiments using multiple nonreactive tracers that vary in their aqueous rate of diffusion. This technique has previously been used to quantify the effects of physical nonequilibrium (PNE) processes in structured media (Jardine et al., 1998, 1999; Langner et al., 1999; Becker and Shapiro, 2000; Moline et al., 2001; Mayes et al., 2003). Physical nonequilibrium results from fast preferential flow coupled with slow diffusion into less mobile water regimes. These phenomena result in separation of tracer BTCs because of differential rate of tracer mobility between fast and slow flowing water regimes.

In an effort to better understand how solutes migrate in semiarid regions, numerous experiments have been conducted in packed columns of silty-sandy media using a single nonreactive tracer (Bond and Wierenga, 1990; Porro and Wierenga, 1993; Padilla et al., 1999; Gamerdinger and Kaplan, 2000). Flow and transport in saturated packed columns typically result in symmetric BTCs, while asymmetric BTCs are observed under unsaturated conditions. As packed columns become unsaturated, the larger pores are drained, resulting in areas of

Abbreviations: bp, bubbling pressure; BTC, breakthrough curve; CDE, convection-dispersion equation; IC, ion chromatograph; MIM, mobile-immobile model; ORNL, Oak Ridge National Laboratory; PFBA, pentafluorobenzoic acid; PIPES, piperazine-1-4-bis(2-ethanesulfonic acid); PNE, physical nonequilibrium; PV, pore volume. 
immobile water (Padilla et al., 1999; Gamerdinger and Kaplan, 2000). Consequently, slow diffusion of tracer into these relatively immobile regions results in more asymmetric BTCs than observed under saturated conditions. The rate of exchange between the mobile and immobile water is typically quantified by modeling BTCs for single nonreactive tracers (Bond and Wierenga, 1990; Porro and Wierenga, 1993; Padilla et al., 1999; Gamerdinger and Kaplan, 2000). Breakthrough asymmetry is not always a good indicator of diffusion controlled mass exchange between different pore water regimes (Becker and Shapiro, 2000); thus, single tracer experiments often lack sufficient information for quantifying PNE processes.

A select few studies have successfully combined the use of multiple nonreactive tracers in miscible displacement experiments with undisturbed, stratified siltysandy media (Mayes et al., 2003) in an effort to quantify PNE processes. Mayes et al. (2003) used the multiple tracer technique to show that undisturbed stratified siltysandy media of the Ringold Formation has differing responses to unsaturated flow depending on the direction of flow relative to the direction of bedding. When flow was parallel to bedding, no tracer separation was observed, which suggested that diffusional exchange between beds was inhibited during unsaturated conditions. When flow was perpendicular to bedding, early breakthrough and separation of tracers was observed, which suggested preferential finger flow, formation of perched water, and diffusional exchange within zones of perched or immobile water occurred during unsaturated conditions. The anisotropic flow and transport behavior exhibited by the Ringold Formation demonstrated the sensitivity of unsaturated flow to small-scale sedimentary and lithologic features.

The study of Mayes et al. (2003) focused on the flow and transport processes of an intensively stratified portion of the Miocene-Pliocene age Ringold Formation that was deposited in a lacustrine environment, followed by several million years of postdepositional alterations. The portion of the Ringold Formation included in Mayes et al. (2003) was composed of small, much finergrained laminated silt and sand beds (centimeter to millimeter scale) than the Hanford Formation. The Pleistocene age Hanford Formation, was formed by the floods of glacial Lake Missoula, and contains deposits such as fine-grained channel fills and coarse-grained flood bars. Such deposits contribute to the wide variation in grain size, which is characteristic of the Hanford formation. The young age of the Hanford formation suggests that less postdepositional alteration of minerals occurred compared with older formations such as the Ringold. Therefore, the diversity in age, sedimentology, and stratigraphy between the two formations demands additional studies to characterize the dominant hydrologic processes in the Hanford Formation. Further, only the use of identical experimental techniques would allow an objective comparison between the Hanford and Ringold Formations.

The goal of this study is to provide an improved understanding of the flow and transport processes that influence the migration of contaminants in the Hanford Formation in the Hanford Reservation vadose zone. The objectives are to use a multiple tracer strategy in miscible displacement experiments to determine the effects of lithological stratification and discontinuities on flow and transport at various moisture contents within the Hanford Formation. Lateral vs. vertical flow will be investigated by comparison of transport through horizontal cores where flow is parallel to bedding and vertical cores where flow is perpendicular to bedding. The presence of preferential flow and matrix diffusion will be determined using multiple nonreactive tracers.

\section{MATERIALS AND METHODS}

\section{Collection of Undisturbed Cores}

The vadose zone beneath the Hanford Reservation is approximately $100 \mathrm{~m}$ deep, with the Hanford Formation comprising the upper $70 \mathrm{~m}$. The Hanford Formation is a Pleistocene age deposit formed from multiple floods of glacial Lake Missoula to the east (Bjornstad, 1990; Lindsay, 1995). It is a heterogeneous media of unconsolidated laminated coarse and fine sands that are interbedded with small-scale clay layering (Fig. 1 and 2). Often boulder- and gravel-sized rocks are intermixed with the media to create a highly heterogeneous pore size distribution.

Undisturbed cores from the Hanford sediments were collected from the Environmental Restoration Disposal Facility in the 200W Area of the Hanford Reservation (Fig. 1). Freshly exposed escarpments were opened at a depth of about $20 \mathrm{~m}$ (Fig. 2), and undisturbed cores were isolated using a handsculpting method described by Jardine et al. (1993) and Reedy et al. (1996). The technique entailed isolating a small pedon, carving the sample to its finished dimensions ( $\approx 20$ by $20 \mathrm{~cm})$, and coating with paraffin wax. A relatively high ambient moisture content facilitated collection of the sandy, unconsolidated media. Figure 3 illustrates the collection of undisturbed horizontal (flow parallel to bedding) and vertical (flow perpendicular to bedding) cores from within a fine-grained layer. The cores were placed in a wood crate, entombed in loose sediment, and shipped to Oak Ridge National Laboratory (ORNL) in a vehicle loaded on a flat bed semi-truck. Disturbed material was also collected for characterization of select soil chemical and physical properties (Table 1) and for the determination of the moisture retention function.

\section{Determination of the Moisture Retention Function}

The moisture retention function was determined for the Hanford Formation material following standard methods (Klute, 1986) on triplicate samples. Brass sleeves, $8.5-\mathrm{cm}$ i.d. and $6 \mathrm{~cm}$ tall, were packed with disturbed media to a bulk density of approximately $1.5 \mathrm{~g} \mathrm{~cm}^{-3}$ (Table 2). Samples were saturated from the bottom with $5 \mathrm{mM} \mathrm{CaCl}$ using a Mariotte device and then placed into a flow cell for pressures from zero to atmospheric (0-1000 $\mathrm{cm}$ of water) (Soil Measurement Systems, Tucson, AZ). For pressures greater than atmospheric, small packed rings (5.4-cm i.d., $1.1 \mathrm{~cm}$ tall) of sediment were placed onto large ceramic plates within the Model 1600 Pressure Extractor (Soil Moisture Co., Santa Barbara, CA). A tension was applied to the samples in the flow cell and allowed to drain. The sample weight was recorded once water loss ceased and the sample weight remained constant. This was repeated over the range of applied tensions. 


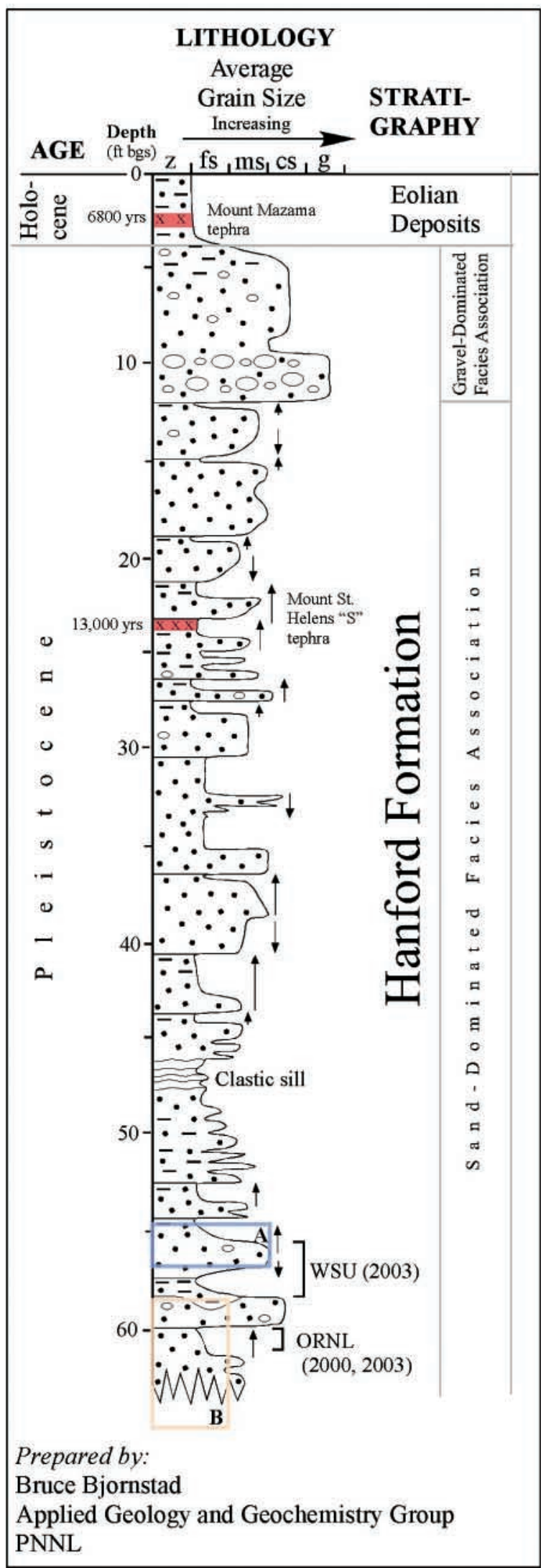

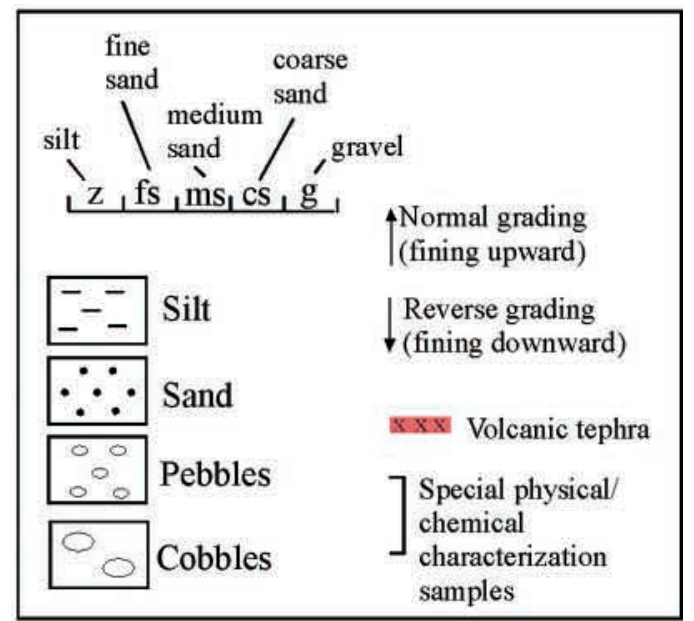

Fig. 1. A stratigraphic column of the vadose zone at the 200W Area Environmental Restoration Disposal Facility on the Hanford Reservation. Note that the undisturbed cores used in this study were collected in August 2000 at the 18.24-m (60-ft) depth. 


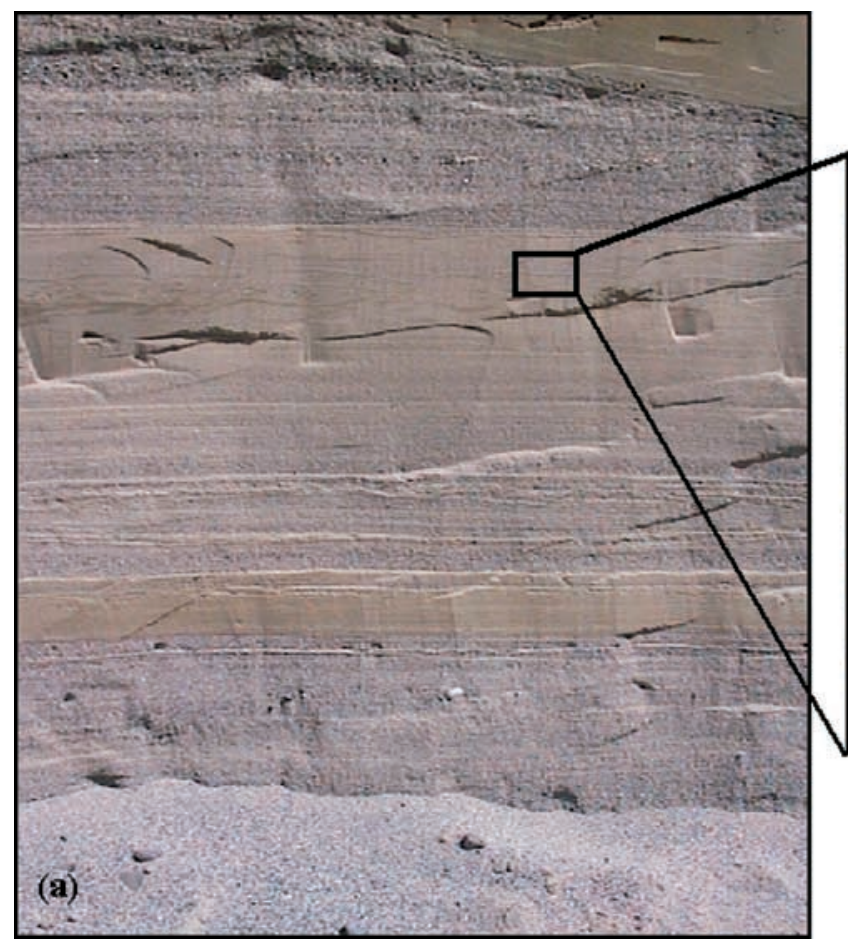

(b)

Fig. 2. Excavation into the Hanford Formation at the 200W Area Environmental Restoration Disposal Facility on the Hanford Reservation, 20-m depth. (a) Unconsolidated alternating layers of coarse and fine sands. (b) Expanded view of fine-grained layer from which cores were collected. Note small-scale clay layering.

\section{Experimental Apparatus}

After core shipment, the wax coating was carefully removed from the large undisturbed sediment cores and PVC pipe was placed over the media. The annulus between the sediment and the PVC was then filled with 3M Gray/White epoxy (3M Company, Ann Arbor, MI) and allowed to harden. Airtight endcaps fabricated from acrylic and PVC were attached to the lower end of the PVC-encased core as shown in Fig. 4. A multichannel peristaltic pump (Watson-Marlow Ltd., Cornwall, England) was used to deliver influent to the upper soil boundary where the top of the core was covered with a nylon membrane $(-30 \mathrm{~cm}$ bubbling pressure [bp]) in an effort to evenly distribute the influent. Each drip point from the peristaltic pump created a circular pattern on the nylon membrane with a diameter of about $3 \mathrm{~cm}$ (larger diameters were observed

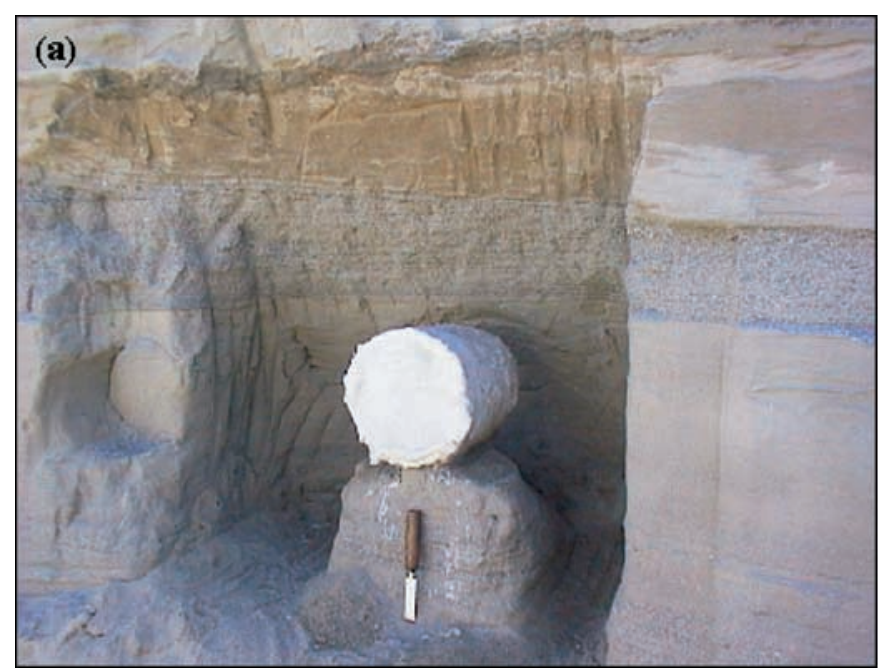

with higher core moisture contents). There were a total of 11 drip points per pump with a total area of the core equal to approximately $314 \mathrm{~cm}^{2}$. The rate of influent delivery for different core saturation levels was estimated from modeled water retention data and generated $K(h)$ functions using the code Retention Curve (van Genuchten et al., 1991). The top of the core was covered with a Plexiglas sheet to minimize evaporation. The lower boundary was maintained with either a -30 or $-600 \mathrm{~cm}$ bp nylon membrane (Soil Measurement Systems) in direct contact with the soil using a perforated aluminum disc held in place by the acrylic-PVC endcap. The -30 and $-600 \mathrm{~cm}$ bp membranes were used in saturated and unsaturated flow experiments, respectively. Tension at the lower boundary was controlled by a vacuum chamber (Soil Measurement Systems) that housed an internal fraction collec-

Fig. 3. Harvesting of undisturbed cores from the Hanford Formation. (a) Paraffin wax-coated horizontal core, and (b) sculpting of vertical core.

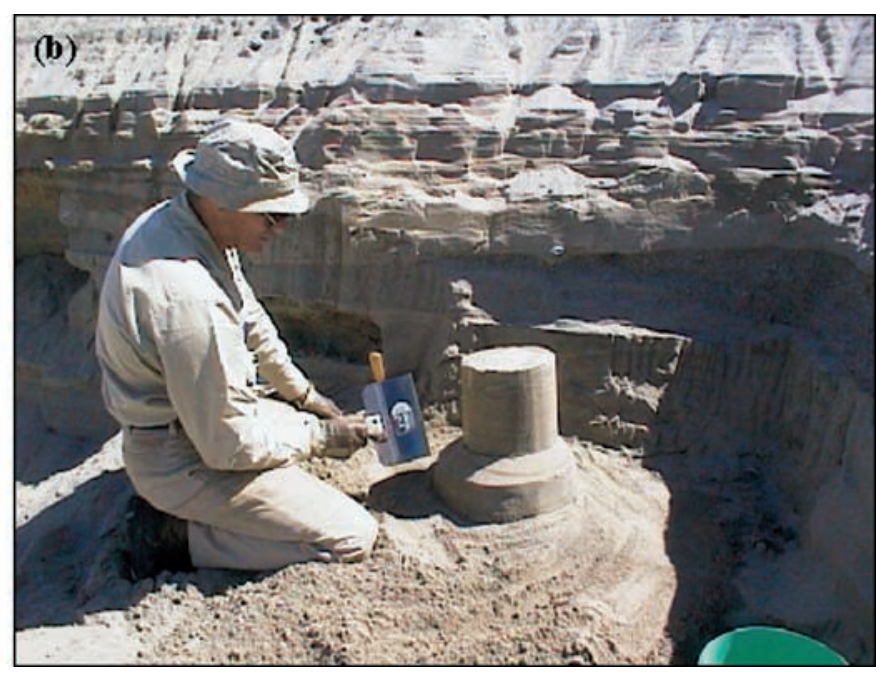


Table 1. Select chemical, physical, and mineralogical characteristics of the Hanford Formation used in this study (Roh et al. 2002).

\begin{tabular}{|c|c|c|}
\hline \multicolumn{3}{|c|}{ Chemical properties } \\
\hline Total inorganic $\mathbf{C}$ & & $0.22 \%$ \\
\hline Total organic C & & $0.02 \%$ \\
\hline Poorly crystalline iron oxides, g Fe $\mathrm{kg}^{-1}$ soil & & 0.51 \\
\hline Total free iron oxides, ${\mathrm{g} \mathrm{Fe} \mathrm{kg}^{-1} \text { soil }}^{\circ}$ & & 4.90 \\
\hline Cation exchange capacity, $\mathrm{cmol} \mathrm{kg}^{-1}$ soil & & 4.88 \\
\hline \multicolumn{3}{|c|}{ Particle size analysis and mineralogy } \\
\hline $95 \%$ Sand $(>50 \mu \mathrm{m})$ & \multirow{4}{*}{\multicolumn{2}{|c|}{$\begin{array}{l}\text { Quartz }>\text { Plagioclase }>\text { Mica }>\text { Kaolinite }>\text { Chlorite }>\text { Calcite } \\
\text { Quartz }>\text { Mica }>\text { Plagioclase }>\text { Kaolinite }>\text { Chlorite }>\text { Smectite } \\
\text { Illite }>\text { Kaolinite }>\text { Chlorite/HIV } \dagger>\text { Smectite }>\text { Quartz }>\text { Plagioclase } \\
\text { Illite }>\text { Kaolinite }>\text { Chlorite/HIV } \dagger>\text { Smectite }>\text { Quartz }>\text { Plagioclase }\end{array}$}} \\
\hline $4 \%$ Silt $(2-50 \mu \mathrm{m})$ & & \\
\hline 1\% Clay $(<2 \mu \mathrm{m})$ & & \\
\hline Fine clay $(<0.2 \mu \mathrm{m})$ & & \\
\hline
\end{tabular}

$\dagger$ Hydroxy-interlayered vermiculite.

tor (Isco Corp., Lincoln, NE). A vacuum gauge (Dwyer Instruments, Michigan City, IN) and regulator (Moore Products, Springhouse, PA) were used to regulate the house vacuum source. Soil tension was measured using tensiometers made of one bar standard ceramic cups (diameter $0.635 \mathrm{~cm}$, length $2.858 \mathrm{~cm}$ ) (Soil Moisture Co.) placed approximately $3 \mathrm{~cm}$ into the undisturbed cores. The tensiometers were used as a qualitative tool to monitor daily matric potentials. Tensiometer readings typically varied slightly from day to day but were usually stable throughout an experiment. Any significant change in the tensiometer readings indicated a possible change in the moisture content of the core, upon which the core was reweighed and a new moisture content was calculated.

\section{Miscible Displacement Experiments}

The undisturbed cores were assembled and weighed before experimentation and corrections were made for ambient water content before saturation. The cores were slowly saturated from the lower boundary using a solution of $5 \mathrm{mM} \mathrm{CaCl} 2, \mathrm{pH}$ adjusted to 8.2 (the soil $\mathrm{pH}$ ) using $\mathrm{NaOH}$ or $\mathrm{KOH}$, and their saturated weights recorded. Solutions were delivered to the saturated cores using a constant head Mariotte device that maintained a ponded water depth of about $1 \mathrm{~cm}$ at the upper boundary of the cores. Saturated miscible displacement experiments were conducted with gravity-induced flow. An estimated saturated pore volume was determined from the $\mathrm{Br}^{-}$ $\mathrm{BTC}$ at $C / C_{0}=0.5$ for each core. Actual values would require destruction of the undisturbed cores, and this was deemed unnecessary considering the future scientific value of the cores.

Upon completion of the saturated experiments, the cores were attached to a vacuum-regulated chamber for unsaturated flow experiments (Fig. 4). The cores were allowed to drain at a desired tension set in the vacuum chamber until water loss ceased and the core weight was again recorded. The carrier solution ( $5 \mathrm{mM} \mathrm{CaCl}_{2}$ or $0.1 \mathrm{M} \mathrm{NaCl}, \mathrm{pH}=8.2$ ) was then delivered to the upper boundary of the cores using a multichannel peristaltic pump (Fig. 4). Samples were collected until the effluent flow rate and the core tensions were stable. The cores were then reweighed. The difference between this weight and the saturated core weight was subtracted from the saturated

Table 2. Moisture retention function experimental parameters.

\begin{tabular}{lc}
\hline Sample $\dagger$ & Bulk density \\
\hline HFH1 & $\mathrm{g} \mathrm{cm}^{-3}$ \\
HFH2 & 1.445 \\
HFH3 & 1.480 \\
HFV1 & 1.480 \\
HFV2 & 1.524 \\
HFV3 & 1.491 \\
\hline
\end{tabular}

$\dagger$ HFV, Hanford fine material collected near the vertical core; HFH, Hanford fine material collected near the horizontal core. The number denotes the number of replicates. pore volume and then divided by the total volume of the core to determine the unsaturated moisture content. Flow of the multiple nonreactive tracer solution was then initiated. A flowinterruption experiment was also initiated on one of the cores, where an interruption in influent flow occurred that lasted $11 \mathrm{~d}$. Flow was reinitiated with the carrier (washout) solution until tracer concentration was less than the detection limit. Flow-interruption experiments provide a method that also identifies the extent of PNE during solute migration (Reedy et al., 1996). All experimental parameters are listed in Table 3.

The nonreactive tracer influent solution used in saturated miscible displacement experiments consisted of $0.5 \mathrm{mM} \mathrm{Br}$ as $\mathrm{CaBr}_{2} \cdot 2 \mathrm{H}_{2} \mathrm{O}, 0.5 \mathrm{~m} M$ PFBA, $1.0 \mathrm{~m} M$ PIPES, $4.4 \mathrm{~m} M$

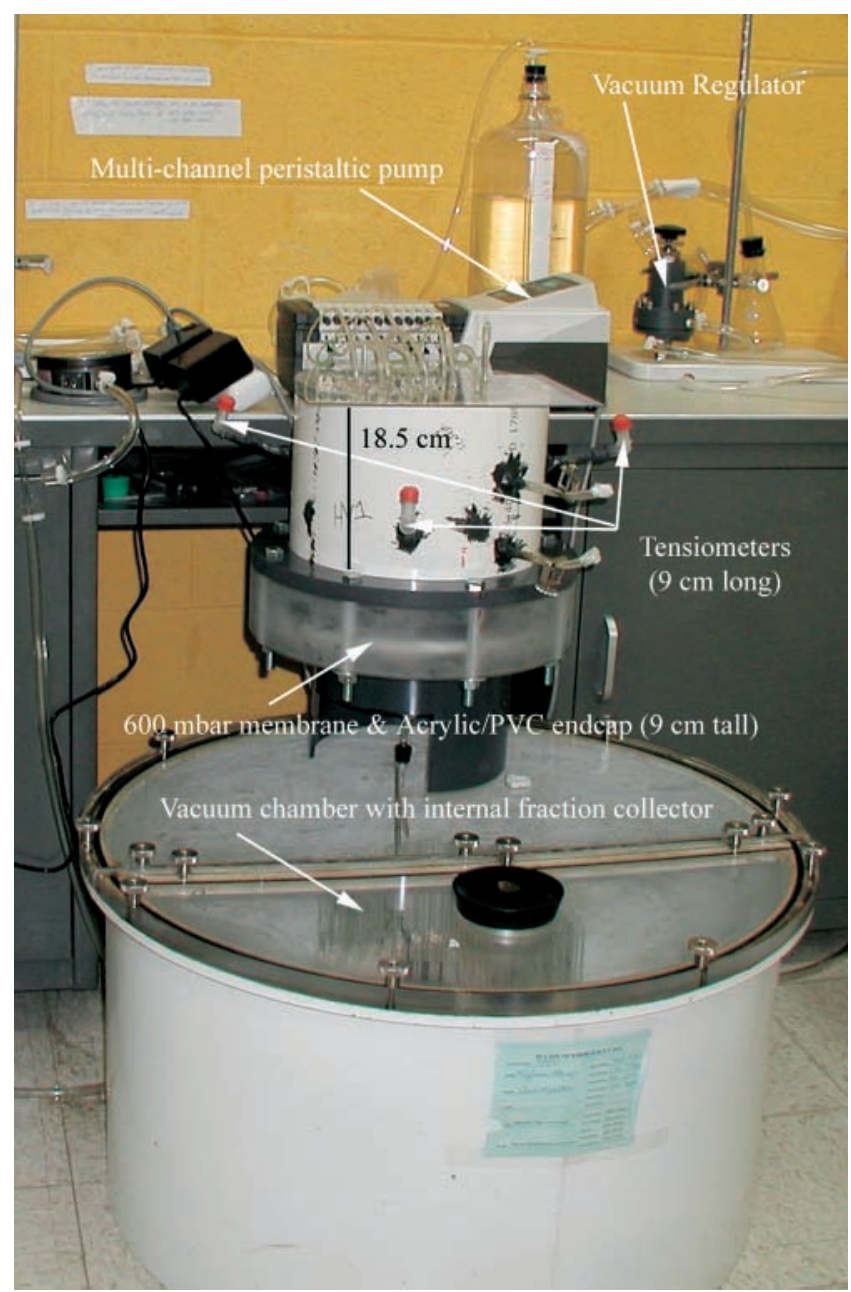

Fig. 4. Experimental apparatus for conducting unsaturated flow experiments in undisturbed cores. 
Table 3. Experimental parameters of undisturbed Hanford Formation saturated and unsaturated miscible displacement experiments. $\dagger$

\begin{tabular}{lcccc}
\hline & \multicolumn{4}{c}{ Experimental parameters } \\
\cline { 2 - 5 } Core & $K_{\text {sat }}$ & Radius & Pulse & $\begin{array}{c}\text { Vacuum chamber } \\
\text { tension }\end{array}$ \\
\hline & $\mathbf{c m ~ h}^{-1}$ & $\mathbf{c m}$ & PV & $\mathrm{cm}$ \\
HH-sat & $\mathbf{1 3 . 6}$ & $\mathbf{1 1 . 0}$ & $\mathbf{7 . 3}$ & $\mathbf{0}$ \\
HV-sat & $\mathbf{2 . 7 7}$ & $\mathbf{1 0 . 5}$ & $\mathbf{2 . 4}$ & $\mathbf{0}$ \\
HH-95\% & & $\mathbf{1 1 . 0}$ & $\mathbf{1 6}$ & $-\mathbf{5 4}$ \\
HV-99\% & & $\mathbf{1 0 . 5}$ & $\mathbf{2 . 3}$ & -60 \\
HH-60\% & & $\mathbf{1 1 . 0}$ & $\mathbf{1 6}$ & $-\mathbf{1 6 0}$ \\
HV-40\% & & $\mathbf{1 0 . 5}$ & $\mathbf{0 . 5 6}$ & $-\mathbf{1 6 0}$ \\
\hline
\end{tabular}

$\dagger$ HH, Hanford horizontal core; HV, Hanford vertical core; PV, pore volume.

$\mathrm{CaCl}_{2}$, and $2.4 \mathrm{~m} M \mathrm{KOH}$, which resulted in an ionic strength of $0.015 M$ consistent with the carrier solution of $5 \mathrm{mM} \mathrm{CaCl}$. For unsaturated displacement experiments, the tracer solution was prepared in $0.1 M \mathrm{NaNO}_{3}$ or $0.1 \mathrm{M} \mathrm{NaCl}$, as was the carrier solution, to be more representative of the far-field vadose zone beneath the Hanford tank farms. The $\mathrm{pH}$ of the tracer and carrier solution was adjusted to 8.2 with $\mathrm{KOH}$ so that the solution $\mathrm{pH}$ was equivalent to that of the soil. The difference in ionic strength between the saturated and unsaturated tracer solution will not effect the elution of the anionic nonreactive tracers. Jardine and Taylor (1995), Moline et al. (2001), and Mayes et al. (2003) used PIPES as a nonreactive tracer. Many investigators used PFBA as a nonreactive tracer in miscible displacement experiments (Bowman, 1984; Bowman and Gibbens, 1992; Hu and Brusseau, 1994, 1995; Jardine and Taylor, 1995; Langner et al., 1999; Gamerdinger and Kaplan, 2000; McCarthy et al., 2000; Kung et al., 2000; Mayes et al., 2003). PIPES and PFBA are both large organic molecules (Fig. 5) that are deprotonated at the experimental $\mathrm{pH}$ values. The chemical structure of each tracer is illustrated in Fig. 5; note the circular shape of PFBA and the linear shape of PIPES. The three nonreactive tracers used in this study $\left(\mathrm{Br}^{-}, \mathrm{PFBA}\right.$, and PIPES) differ in molecular size and therefore their freewater diffusion coefficient. Table 4 lists each tracer's free-water diffusion coefficient as well as $\mathrm{p} K_{\mathrm{a}}$ values for PIPES and PFBA. The molecular diffusion coefficients for PIPES and PFBA have been calculated according to the Hayduk and Laudie (1974) method (Tucker and Nelken, 1982). This method applies to large spherical molecules diffusing in a continuous solution. The linear shape of PIPES may result in greater error associated with its diffusion coefficient estimate; however, no published estimates for PIPES are available. The PFBA diffusion coefficient calculated by this method differs from published estimates by about 5\% (Bowman, 1984; Benson and Bowman, 1994). The Hayduk and Laudie method was used for internal consistency when estimating the PIPES and PFBA diffusion coefficients.

The concentration of $\mathrm{Br}^{-}, \mathrm{PFBA}$, and PIPES was quantified simultaneously using a low-pressure liquid chromatography system with UV detection (190 nm) (Model DX-300 and DX600 Gradient Pump, Dionex Corp., Sunnyvale, CA). An eluent
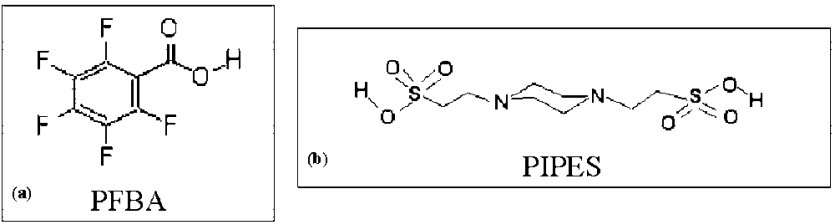

Fig. 5. Chemical structure of two large organic molecules that are used as nonreactive tracers. (a) Pentafluorobenzoic acid (PFBA) and (b) piperazine-1-4-bis(2-ethanesulfonic acid) (PIPES).
Table 4. Physical characteristics of the nonreactive tracers (Mayes et al., 2003).

\begin{tabular}{|c|c|c|}
\hline Tracer & Diffusion coefficient $\left(D_{\mathrm{e}}\right)$ & $\mathbf{p} K_{\mathrm{a}}$ \\
\hline \multicolumn{3}{|c|}{$\mathbf{m}^{2} \mathbf{s}^{-1}$} \\
\hline $\mathbf{B r}^{-}$ & $18.7 \times 10^{-10} \dagger$ & $2 \overline{7} \S$ \\
\hline $\begin{array}{l}\text { PFBA } \\
\text { PIPES }\end{array}$ & $\begin{array}{l}7.8 \times 10^{-10} \uparrow \\
5.2 \times 10^{-10} \leftarrow\end{array}$ & $\begin{array}{c}2.7 \S \\
<\mathbf{3}, \mathbf{6 . 8} \text { | }\end{array}$ \\
\hline
\end{tabular}

$\dagger$ Bowman (1984).

$\$$ Calculated by the Hayduk and Laudie (1974) method (Tucker and Nelken, 1982).

$\S$ McCarthy et al. (2000); Benson et al. (1994).

Il Good et al. (1966).

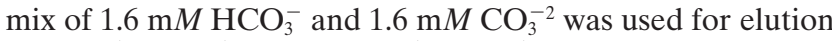
of $\mathrm{Br}^{-}$(3.0 min) and PFBA (3.2 min) in an AS-4A column with a flow rate of $2 \mathrm{~mL} \mathrm{~min}^{-1}$. For the elution of PIPES $(6.8$ $\mathrm{min}$ ), the eluent mix was increased at $1.8 \mathrm{~min}$ to $4.8 \mathrm{mM}$ $\mathrm{HCO}_{3}^{-}$and $4.8 \mathrm{mMCO} \mathrm{CO}_{3}^{-2}$. For samples with high $\mathrm{Cl}^{-}$, the AS-9 column was used with an eluent mix of $9 \mathrm{mM} \mathrm{CO}_{3}^{-2}$ and

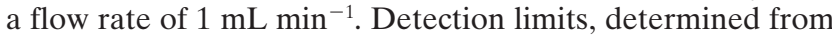
standard curves, were approximately $0.005 \mathrm{mM}$ for $\mathrm{Br}^{-}$and PFBA, and $0.02 \mathrm{~m} M$ for PIPES. A total organic C analyzer (Model \#TOC-5000, Shimadzu, Japan) was also used to determine mass recovery and to confirm the total concentrations of PIPES and PFBA.

\section{Modeling the Displacement Experiments}

The steady-state transport of multiple nonreactive tracers through saturated and unsaturated undisturbed cores was mathematically described using two codes based on the convection-dispersion equation (CDE): CXTfit (Parker and van Genuchten, 1984a) and Stopflow (Reedy et al., 1996). Fluxaveraged effluent concentrations were used in all modeling, as it is more appropriate for conditions with lower $P_{\mathrm{e}}$ values (Parker and van Genuchten, 1984b; van Genuchten and Wierenga, 1986; Jardine et al., 1988; Schulin et al., 1987; Barry and Sposito, 1988). In the absence of physical nonequilibrium processes (i.e., no tracer separation), the CDE model in CXTfit was used to describe transport. In the presence of perceived PNE (separation of tracers), the mobile-immobile model (MIM) in CXTfit should be used to describe the experimental data. Input parameters for CXTfit were effluent concentrations $\left(C / C_{0}\right)$, length of core $L(\mathrm{~cm})$, time (pore volume), mean water pore velocity $V\left(\mathrm{~cm} \mathrm{~h}^{-1}\right)$ where $V=$ flow ratel $\left(\pi r^{2} \theta\right)$, input pulse, and the retardation factor $R$. Theoretically, $R=1$ for conservative nonreactive tracers, and this was true for experiments conducted near saturation. A dispersion coefficient $D\left(\mathrm{~cm}^{2} \mathrm{~h}^{-1}\right)$ was determined for each tracer by a singleparameter curve fit while all other parameters remained fixed when using the CDE model. In the MIM model optimized parameters $\beta$ (dimensionless $F$, where $F$ is the fraction of mobile water), $\omega$ (dimensionless $\alpha, \mathrm{h}^{-1}$, where $\alpha$ is the first-order rate coefficient), and $D$ were determined by fitting the model to the observed data holding all other parameters constant.

Mathematically, flow interruption can be accounted for in the MIM with Stopflow option (Stopflow computer code) by assuming $V=0$ and $D=D_{\mathrm{o}}=D_{\mathrm{e}} / \tau$ during conditions where flow has been temporarily stopped $\left(D_{\mathrm{e}}\right.$ and $D_{\mathrm{o}}$ are the effective and actual molecular diffusion coefficient, respectively, and $\tau$ is a tortuosity factor). Therefore, it is assumed that transport of nonreactive tracers during flow interruption can be described by molecular diffusion within the mobile water regime and the rate of exchange between the mobile and immobile phase (Reedy et al., 1996). For model simulations of experimental data, $D$ was estimated by the CDE in CXTfit for each nonreactive tracer using only the breakthrough portion of the 


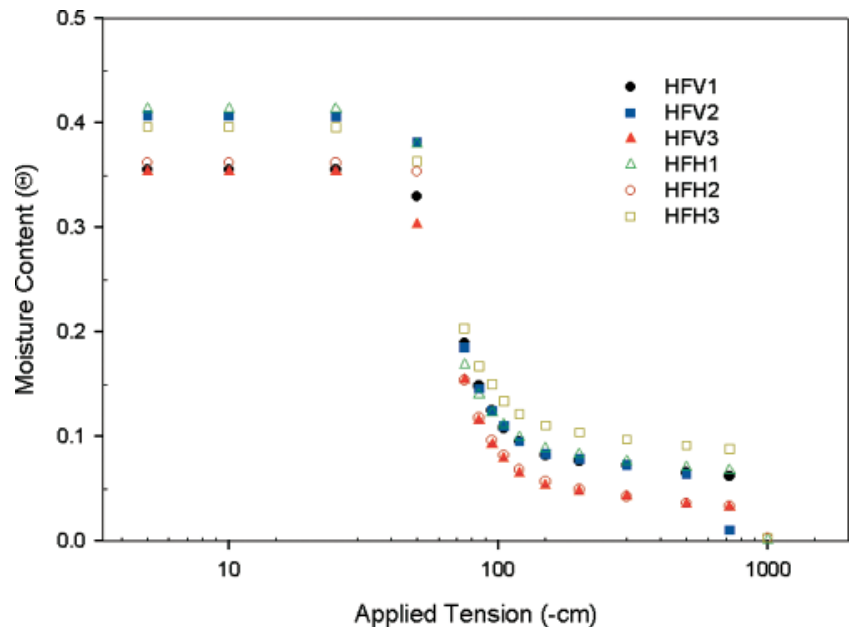

Fig. 6. Moisture retention functions of disturbed sediments of Hanford Formation. Symbols represent observed data. (HFV = Hanford fine material collected near the vertical core, $\mathrm{HFH}=$ Hanford fine material collected near the horizontal core. The number denotes the number of replicate experiments).

data. The computer code Stopflow was then used to simulate the experimental data using $D$ estimated by the CDE. Input parameters for Stopflow are the same as for CXTfit in addition to $\tau(\tau=0.7)$, which was observed to have very little effect on the model results. All physical parameters were held constant and $\alpha$ was varied to best simulate the experimental data. Values of $\alpha$ were chosen that best described the observed concentration perturbations that resulted after the flow interruption. This criterion was used since mass transfer $(\alpha)$ between pore regimes is essentially the only process occurring during flow interruption (Reedy et al., 1996).

\section{RESULTS AND DISCUSSION}

\section{Moisture Retention Function}

Moisture retention functions (Fig. 6) were determined for the Hanford Formation to quantify the drainage characteristics of the media. The initial saturated water content for all samples was approximately 0.40 and the air-entry tension was approximately $-30 \mathrm{~cm}$ of applied tension, which was similar to that observed in Connelly et al. (1992) for fine-grained Hanford Formation media. Water loss was rapid until approximately $-200 \mathrm{~cm}$ applied tension. The residual moisture content was about 0.05 , which also was similar to that of Connelly et al. (1992).

\section{Miscible Displacement Experiments}

\section{Saturated Flow and Transport}

Flow and transport through undisturbed cores under saturated conditions were mainly controlled by the direction of flow relative to bedding and the high pore water velocity obtained by gravity-induced flow. Relatively asymmetric BTCs coupled with the synonymous breakthrough of the multiple tracers for both vertical and horizontal cores suggested an advective-dominated flow system (Fig. 7). Due to the method of saturation of the cores, air entrapment should not be disregarded as a possible cause for preferential flow and asymmetric
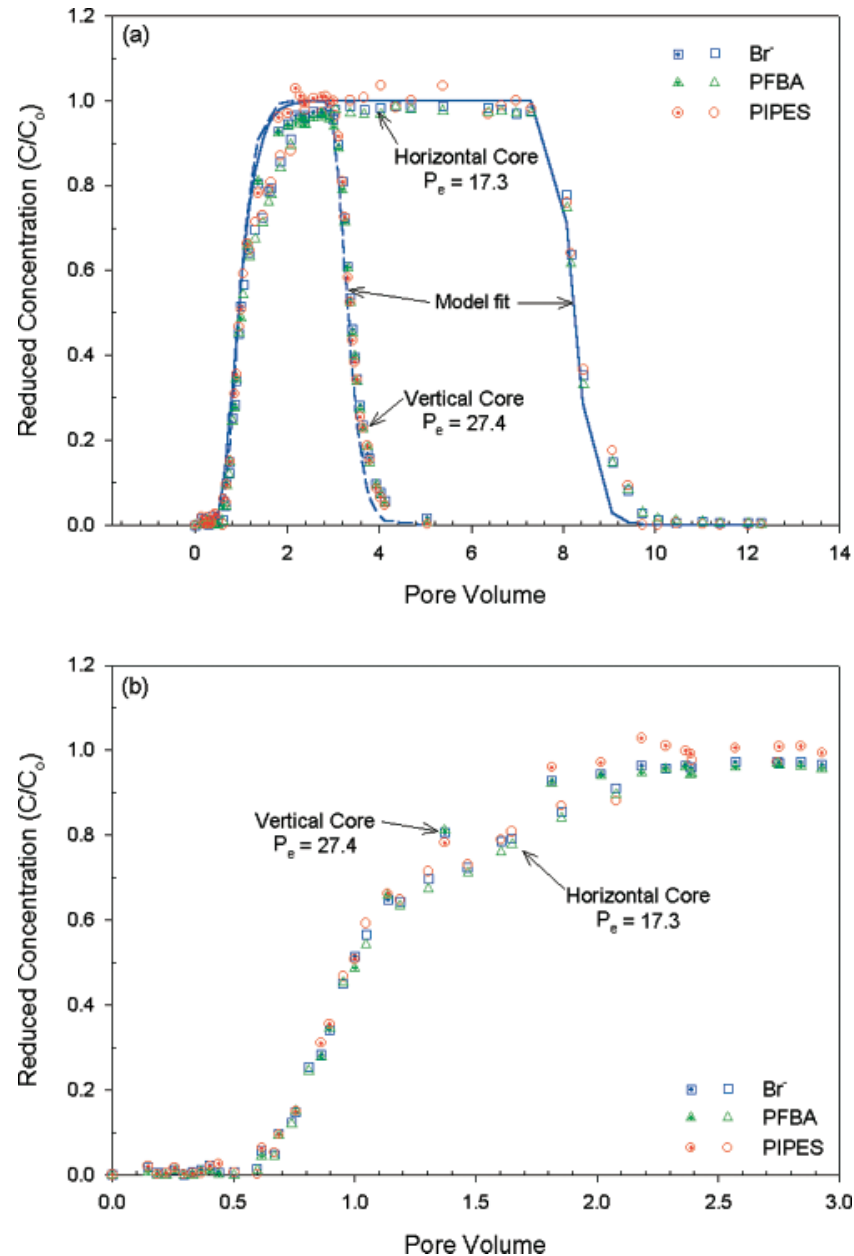

Fig. 7. Observed (symbols) and model fitted (lines) tracer effluent concentrations involving the displacement of $\mathrm{Br}^{-}, \mathrm{PFBA}$, and PIPES through saturated cores. Modeled $\mathrm{Br}^{-}$relative concentrations are shown with model parameters provided in Table 5. Modeled PFBA and PIPES were omitted to improve clarity of figure, since no significant difference in modeled BTCs were observed.

BTCs. Other possible reasons for the observed asymmetric BTCs are non-Fickian dispersion and heterogeneity of the media. The lack of observed tracer separation indicated that diffusive processes and the presence of immobile water regimes were minimal during saturated conditions, possibly due to the high pore water velocities (Mayes et al., 2003). Simultaneous initial tracer breakthrough was observed in both the horizontal and vertical cores. However, at later times (1.2-2.5 pore volumes [PV]) (Fig. 7b) tracer concentrations in the vertical core were greater than the horizontal core because of greater advective-dominated flow parallel to bedding. In the horizontal core, flow is parallel to beds that have wide variations in pore velocity causing greater dispersion in the horizontal core. In the vertical core, flow crosses all beds and can only proceed as fast as the slowest pore water velocity, resulting in greater symmetry in the BTC. The tracer BTCs were adequately fit with the CDE model; the results for $\mathrm{Br}^{-}$are shown in Fig. 7 and Table 5. The adequacy of the model was consistent with the lack of matrix diffusion processes or immobile water influencing tracer migration. The differ- 
Table 5. Modeling results of undisturbed Hanford Formation saturated and unsaturated breakthrough (BTC) data. $\dagger$

\begin{tabular}{|c|c|c|c|c|c|c|c|c|c|c|}
\hline & \multirow{2}{*}{$\begin{array}{c}\text { Mass } \\
\text { recovery }\end{array}$} & \multirow[b]{2}{*}{ Model } & \multicolumn{8}{|c|}{ Model parameters } \\
\hline & & & $\boldsymbol{R}$ & $V$ & $L$ & $P_{\mathrm{e}}$ & $\boldsymbol{\theta}$ & $\boldsymbol{F}$ & $\alpha$ & $r^{2}$ \\
\hline & $\%$ & & & $\mathrm{~cm} \mathrm{~h}^{-1}$ & cm & & & & $\mathbf{h}^{-1}$ & \\
\hline HH-sat $\mathrm{Br}^{-}$ & 97 & CDE & 1 & 41.92 & 23 & $17.30 \pm 10.62$ & 0.3250 & NA & NA & 0.9673 \\
\hline HV-sat $\mathrm{Br}^{-}$ & 98 & CDE & $\mathbf{1}$ & 12.00 & 21 & $27.37 \pm \mathbf{9 . 5 8}$ & 0.4090 & NA & NA & 0.9782 \\
\hline HH-95\% Br ${ }^{-}$ & 101 & CDE & 1 & 0.0961 & 23 & $5.87 \pm 7.26$ & 0.3097 & NA & NA & 0.9409 \\
\hline PFBA & 82 & CDE & 1 & 0.0961 & 23 & $6.10 \pm 18.81$ & 0.3097 & NA & NA & 0.8503 \\
\hline PIPES & 99 & CDE & 1 & 0.0961 & 23 & $11.55 \pm 3.56$ & 0.3097 & NA & NA & 0.9929 \\
\hline HV-99\% Br ${ }^{-}$ & 100 & MIM & 1 & 0.0753 & 21 & $6.67 \pm 2.79$ & 0.4089 & 0.80 & $4.17 \mathrm{e}-4$ & NA \\
\hline PFBA & 87 & MIM & 1 & 0.0753 & 21 & $6.02 \pm 3.27$ & 0.4089 & 0.80 & $2.08 \mathrm{e}-4$ & NA \\
\hline PIPES & 111 & MIM & 1 & 0.0753 & 21 & $9.58 \pm 4.91$ & 0.4089 & 0.80 & $4.17 \mathrm{e}-3$ & NA \\
\hline HH-60\% Br ${ }^{-}$ & 94 & CDE & $\mathbf{0 . 5 7 0 6} \pm \mathbf{0 . 0 3 0}$ & 0.1196 & 23 & $10.86 \pm 1.76$ & 0.1978 & NA & NA & 0.9836 \\
\hline PIPES & 93 & CDE & $\mathbf{0 . 5 7 0 6} \pm \mathbf{0 . 0 3 0}$ & 0.1196 & 23 & $7.51 \pm 2.38$ & 0.1978 & NA & NA & 0.9890 \\
\hline $\mathrm{HV}-\mathbf{4 0} \% \mathrm{Br}^{-}$ & 95 & CDE & $\mathbf{0 . 4 6 5 8} \pm \mathbf{0 . 0 1 4}$ & 0.1521 & 21 & $13.61 \pm 3.32$ & 0.1614 & NA & NA & 0.9643 \\
\hline PIPES & 95 & CDE & $\mathbf{0 . 4 6 5 8} \pm \mathbf{0 . 0 1 4}$ & 0.1521 & 21 & $17.89 \pm 4.52$ & 0.1614 & NA & NA & 0.9705 \\
\hline
\end{tabular}

$\dagger$ MIM, mobile- immobile model (with Stopflow option); CDE, convection-dispersion equation model; $R$, retardation factor; $V$, mean pore water velocity; $L$, length of core; $P_{e}$, Peclet number; $\theta$, water content: $\theta=\left[\left(\mathrm{PV}_{\text {saturated }}-\Delta\right.\right.$ Saturated and unsaturated weight $\left.\left.) 1000\right] / V_{t}\right) ; F$, fraction mobile water; $\alpha$, mass transfer coefficient $\left(h^{-1}\right)$.

ences between the horizontal and vertical cores are reflected in the lower Peclet numbers $\left(P_{\mathrm{e}}\right)$ and higher mean pore water velocity for the horizontal vs. the vertical core (Table 5). The difference in observed dispersion in the horizontal and vertical core is a result of the anisotropy of the Hanford Formation and suggests a preference for lateral vs. vertical flow.

\section{Unsaturated Flow and Transport}

$\mathrm{Br}^{-}$Tracer. Unsaturated flow in both horizontal and vertical cores (Fig. 8a and 8b) resulted in earlier initial $\mathrm{Br}^{-}$tracer elution compared with saturated conditions but more asymmetric BTCs at 95 and $99 \%$ saturation and increasingly symmetric BTCs at 60 and $40 \%$ saturation. These results are evidence of preferential finger flow and the development of immobile water due to multiregion flow (Padilla et al., 1999; Gamerdinger and Kaplan, 2000; Mayes et al., 2003). During unsaturated flow, larger pores are drained, resulting in partial disconnection of the primary porosity from the predominant flow paths. Regions of immobile water can develop, allowing for mass exchange between immobile and mobile regions (e.g., preferential flow paths) to occur at water contents near saturation, which is typically governed by diffusive processes (Mayes et al., 2003). However, as water content decreases (60 and $40 \%$ saturated experiments) the flow path is isolated to fine-grained layers, and less interaction with the immobile water occurs resulting in more symmetric BTCs, as evidence by higher $P_{\mathrm{e}}$ values (Table 5). Such physical nonequilibrium processes are evidenced by more asymmetric BTCs, early breakthrough of tracers (Fig. 8), and lower $P_{\mathrm{e}}$ values (Table 5) compared with saturated flow. The results are similar to unsaturated experiments in packed semiarid media (Padilla et al., 1999; Gamerdinger and Kaplan, 2000) and flow cross bedding cores from the Ringold Formation (Mayes et al., 2003), which show early breakthrough and more asymmetric BTCs relative to saturated conditions. However, these results differ from Ringold flow bedding parallel cores of horizontally bedded sediments, which exhibited minimal difference from saturated conditions (i.e., no preferential flow or matrix diffusion) (Mayes et al., 2003). This clearly sug- gests that different hydrologic processes govern unsaturated transport in the Hanford vs. the Ringold Formation. Diffusion into immobile water is restricted in the Ringold flow bedding parallel cores because of the development of capillary barriers in the fine-grained bed-
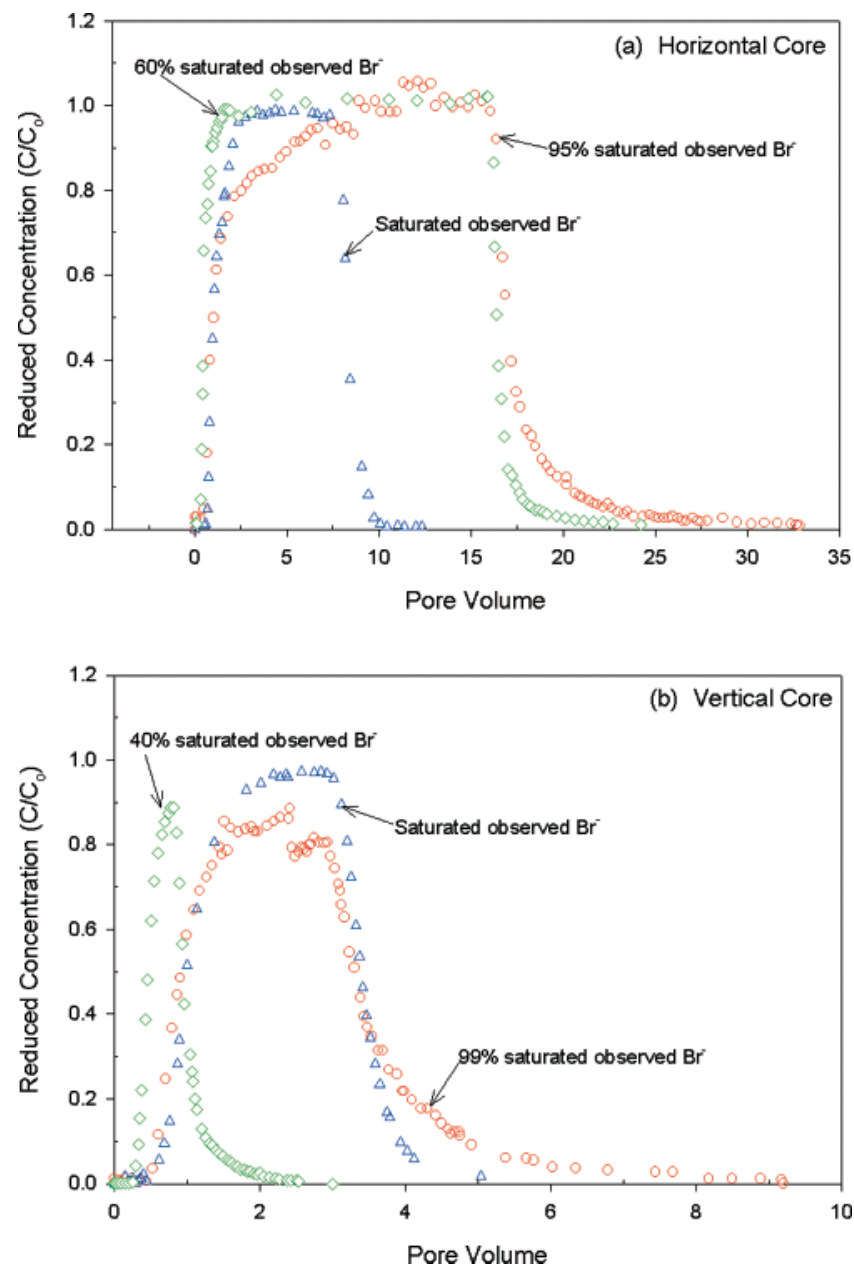

Fig. 8. Observed tracer effluent concentrations involving the displacement of $\mathrm{Br}^{-}$through saturated and unsaturated cores. (a) Breakthrough curve (BTC) for the horizontal core under saturated and unsaturated conditions. (b) BTC for the vertical core under saturated and unsaturated conditions. 
ding. In contrast, diffusion of tracers into immobile water is observed in the Hanford flow bedding parallel cores because of the presence of two distinct porosities - fine sands and clays (Fig. 2b) - active at these water contents. These variations in results demonstrate the importance of small-scale differences in sedimentary structures when predicting flow and transport in unsaturated laminated silts and sands.

Multiple Tracers. Observed separation of tracers and early breakthrough in the unsaturated horizontal core (flow parallel-bed) and vertical core (flow cross-bed) was also suggestive of physical nonequilibrium processes such as matrix diffusion and preferential finger flow (Fig. 9 and 10). Differential tracer diffusion into immobile water most likely results in the observed tracer separation during breakthrough and washout. Ideal results should indicate the concentration: PIPES $>$ PFBA $>\mathrm{Br}^{-}$during breakthrough and washout since the $D_{\mathrm{e}}$ is: $\mathrm{Br}^{-}>$PFBA $>$PIPES (Table 4). Larger molecules with lower $D_{\mathrm{e}}$, such as PIPES, are slower to diffuse into immobile water, thus should breakthrough or washout first. However, as tracers approach equilibrium, crossover of tracer concentration profiles should occur since tracers with larger $D_{\mathrm{e}}$, such as $\mathrm{Br}^{-}$, should reach equilibrium first. This is shown experimentally and numerically by Jardine et al. $(1998,1999)$ and Gwo et al. (1998). In the current study, tracer breakthrough and washout patterns were consistent with this scenario, for the most part, with larger separations of the tracer concentration being observed for the vertical core (Fig. 10) vs. the horizontal core (Fig. 9). This suggested a greater propensity for immobile water regimes to develop in vertical cores where flow crosscuts sediment beds of varying grain size. The enhanced formation of immobile water in vertical cores is consistent with the development of unstable wetting fronts and immobile, perched water in stratified media, where a positive water head is needed for flow to occur (Mayes et al., 2003). In horizontal cores, flow is much more restrictive since it occurs along bedding, minimizing the interaction with immobile water, and thus the transfer of mass between beds is minimized as water content decreases.

Although the tracer breakthrough patterns are consistent with the presence of physical nonequilibrium processes, our data deviate from the ideal trends in two ways. First, PFBA exhibits partial reactive behavior $\left(C / C_{0}\right.$ plateaus near 0.8$)$. Second, PIPES reaches equilibrium very rapidly, avoiding tracer crossover, which is suggestive of pore exclusion characteristics. The breakthrough and washout of PIPES compared with the other tracers is consistent with its large size and slow molecular diffusion rate. The early approach to equilibrium, however, suggested that PIPES was less likely to interact with immobile water regimes during transport, which may be related to size exclusion. The plateau region of the PFBA BTC was significantly removed from equilibrium, which suggested possible reactivity with the solid phase (Fig. 9a). PFBA has successfully been used as a nonreactive tracer in previous investigations $(\mathrm{Hu}$ and Brusseau, 1994; Jardine et al., 1998; Langner et al., 1999; Kung et al., 2000; Mayes et al., 2003). However, the results of this study suggest that PFBA was reactive or degraded at longer times, as it never reached $C / C_{0}=1$. Effluent samples were reanalyzed on the ion chromatograph (IC) and confirmed the original IC data. Total organic $\mathrm{C}$ analysis of effluent samples confirmed that PIPES and PFBA $C$ was similar to that measured by IC. Mass balance of PFBA was $82 \%$ by both IC and TOC methods (Table 5), which strongly suggests that PFBA was either irreversibly sorbed or degraded. Geochemical reactivity is improbable since the system $\mathrm{pH}$ is 8.2 and the charge on PFBA and the solid phase will both be negative. Biological reactivity is a possibility since certain bacteria have been isolated that can degrade 4-fluorobenzoate and use it as their sole $\mathrm{C}$ source (Oltmanns et al., 1989; Jaynes, 1994; Song et al., 2000; Carvalho et al., 2002). Microbiological work was conducted to confirm this hypothesis. A phosphate-buffered minimal medium that consisted of $\mathrm{KCl}$ and $\mathrm{NaCl}$ and trace minerals was inoculated (25X dilution) with effluent from the core. The effluent contained $1.9 \times 10^{6}$ cells $\mathrm{mL}^{-1}$ as determined with acridine orange direct counts, and the inoculum was incubated in the presence of PFBA $(0.6 \mathrm{mM})$ at $26^{\circ} \mathrm{C}$ for approximately $60 \mathrm{~d}$. Ion chromatograph analysis indicated that PFBA had decreased 1.6X compared with controls, and that microbial cell numbers had increased. The results suggested that microorganisms possibly indigenous to the column were able to utilize PFBA or at least degradative byproducts. Further work is needed to determine the processes involved in PFBA utilization and to identify the responsible microorganism(s) (M. Fields, ORNL, 2003, personal communication). Nevertheless, the observed order of tracer separation during early breakthrough and washout is similar to studies that have used $\mathrm{Br}^{-}$ and PFBA in highly heterogeneous structured media that consists of a vast array of pore domains (Gwo et al., 1998; Jardine et al., 1998, 1999, 2001; Langner et al., 1999; Kung et al., 2000; Mayes et al., 2003). The observed order of tracer separation is different from that observed in the Ringold Formation (Mayes et al., 2003), where perched water in vertical or cross-bedded cores caused a reversal of the order of tracer separation. Perched water was not observed in the Hanford Formation cores, most likely because it is dominated by fine sands whereas the Ringold is dominated by silt-sized particles. This supports the notion that the Upper Ringold and Hanford are distinct sedimentary units with different hydrologic transport properties.

In an effort to further substantiate the presence of PNE during solute transport, a flow interrupt was administered on the vertical core $(99 \%$ saturated) at approximately $2.3 \mathrm{PVs}$ for a duration of approximately $11 \mathrm{~d}$ (Fig. 10). Once flow was reinitiated, a significant concentration perturbation was observed for $\mathrm{Br}^{-}$and PFBA but not for PIPES. The concentration perturbations for PFBA and $\mathrm{Br}^{-}$indicated that these tracers were not in equilibrium with the pore water during transport, most likely due to rate-limited diffusion into immobile regions (Murali and Aylmore, 1980; Brusseau et al., 1989, 1997; Koch and Fluhler, 1993; Reedy et al., 1996; Mayes et al., 2000). The lack of an observed con- 

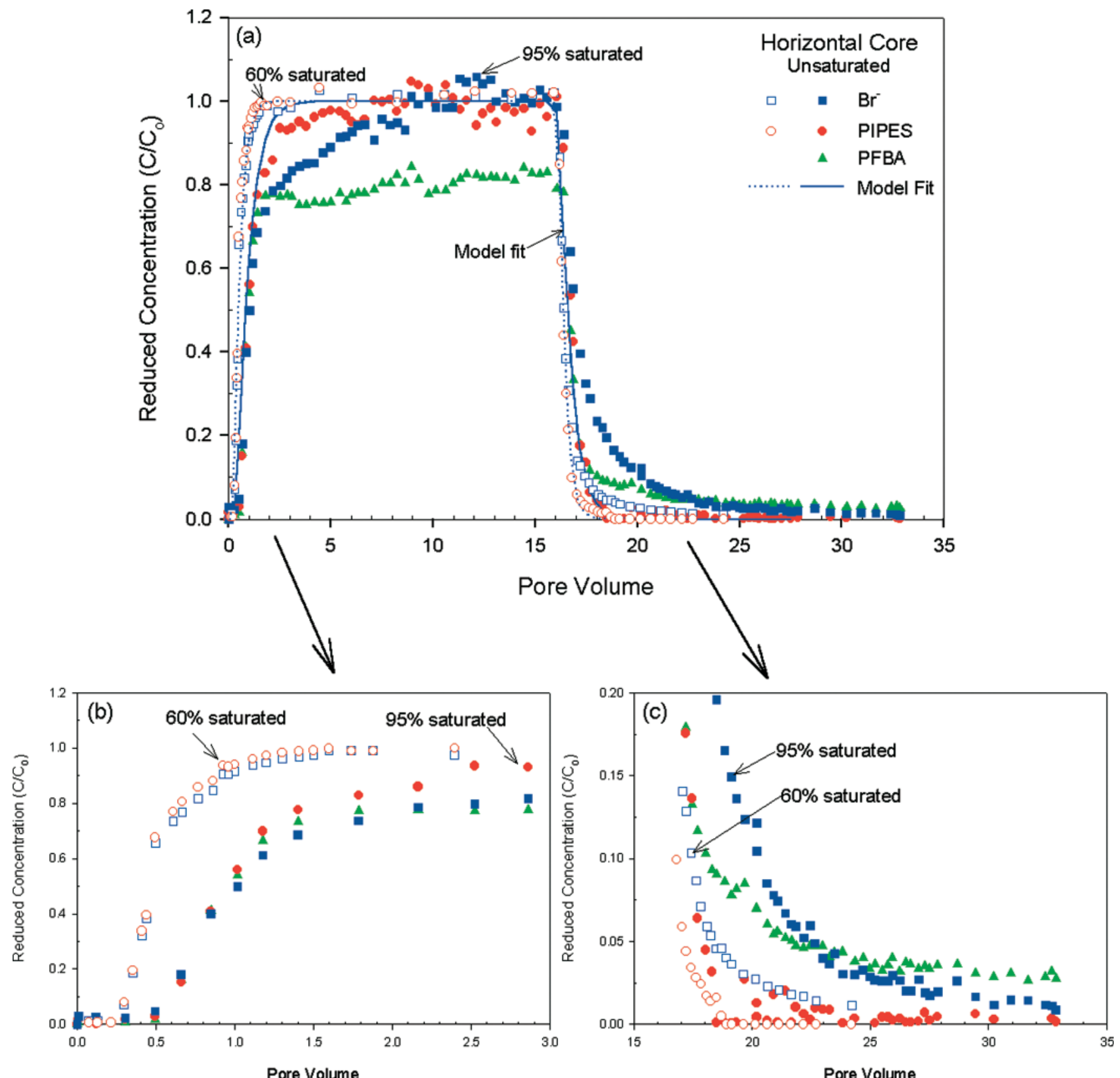

Fig. 9. (a) Observed (symbols) and model fitted (lines) tracer effluent concentrations involving the displacement of $\mathrm{Br}^{-}$, PFBA, and PIPES through the unsaturated horizontal core. Modeled $\mathrm{Br}^{-}$concentrations are shown with the model parameters provided in Table 5. Modeled PFBA and PIPES concentrations were omitted to improve clarity of figure. (b) Observed initial tracer breakthrough showing separation and crossover of tracers. (c) Observed tracer concentration during washout showing separation and crossover of tracers.

centration perturbation for PIPES is consistent with the observation that PIPES had reached an apparent equilibrium condition (i.e., $C / C_{0}=1$ ) before $\mathrm{Br}^{-}$and PFBA. However, PIPES has the smallest diffusion coefficient (Table 4) and should be the last to reach equilibrium with the immobile water. Therefore, the rapid approach to equilibrium and the lack of perturbation in PIPES suggest that this tracer may have been excluded from some portions of immobile water in the undisturbed cores possibly because of its large, bulky size (Fig. 5).

The MIM model with a flow-interrupt option (computer code Stopflow) was used to simulate the vertical core BTC, resulting in an estimation of $20 \%$ immobile water and mass transfer rates between mobile and immobile domains ranging from $4 \times 10^{-4}$ to $4 \times 10^{-3} \mathrm{~h}^{-1}$ for the various tracers (Table 5). The transfer coefficient $(\alpha)$ of each tracer should correspond with their diffusion coefficient so that: $\mathrm{Br}^{-}>$PFBA > PIPES. However, the transfer coefficients $(\alpha)$ obtained from the MIM (Table 5) were an order of magnitude greater for PIPES than for PFBA and $\mathrm{Br}^{-}$, which is surprising given the slow rate of diffusion for PIPES. It is hypothesized that size exclusion of PIPES may be related to inaccessibility of PIPES to immobile water regimes within clay layers 

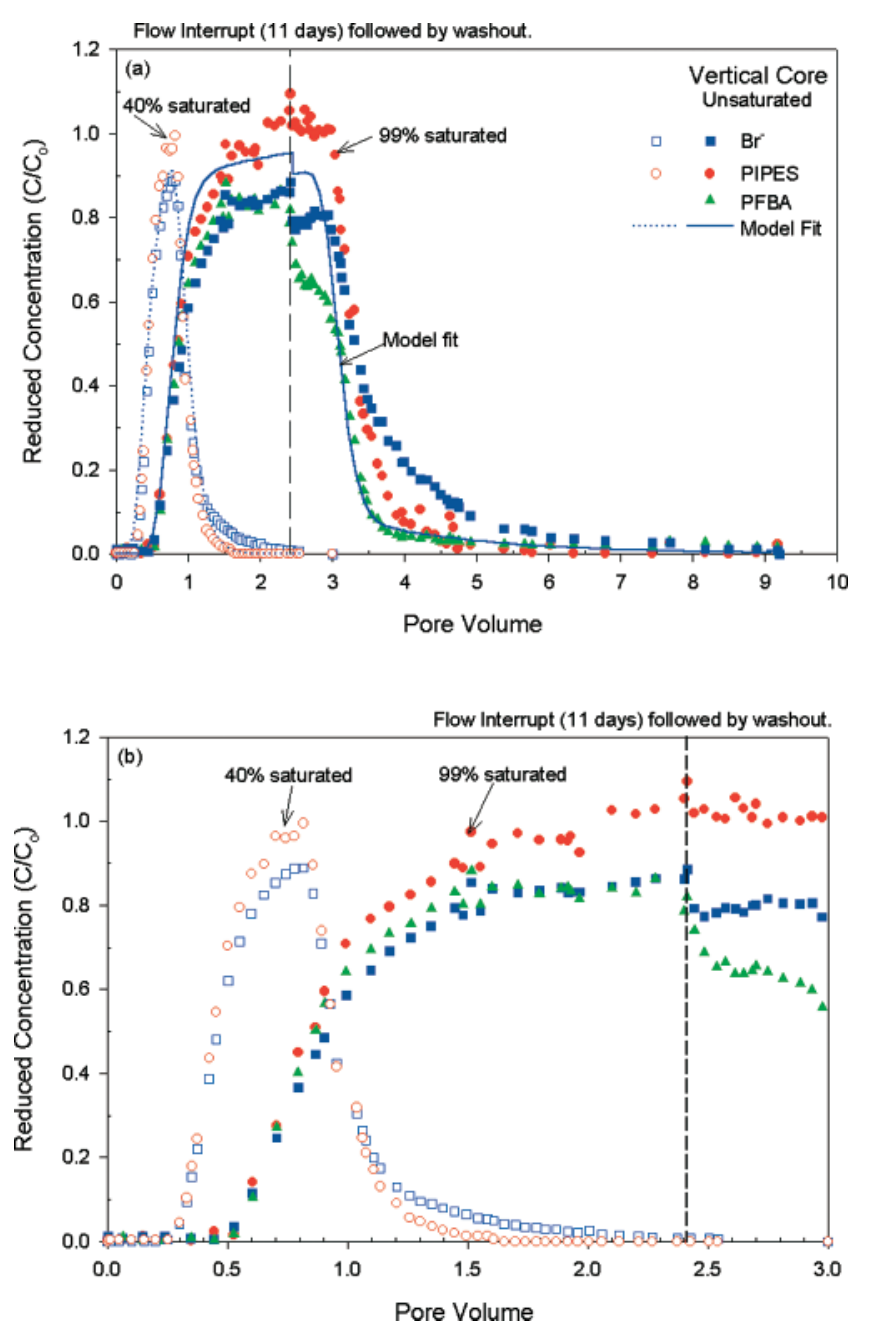

Fig. 10. (a) Observed (symbols) and model fitted (lines) tracer effluent concentrations involving the displacement of $\mathrm{Br}^{-}, \mathrm{PFBA}$, and PIPES through the unsaturated vertical core. Modeled $\mathrm{Br}^{-}$concentrations are shown. Modeled PFBA and PIPES were omitted to improve clarity of figure. (b) Separation of tracers before the flow interruption in the unsaturated vertical core experiment. Model parameters are provided in Table 5.

prominent in the Hanford Formation (Fig. 2), resulting in a higher $\alpha$ value than would be expected for PIPES, no observed perturbation in the flow-interrupt experiment, and a rapid rise to equilibrium. These conclusions could have implications concerning the transport of bulky organic complexes beneath the tank farms.

Tracer separation, asymmetric, and early breakthrough behavior suggests the presence of more than one pore domain within the horizontal core; therefore, the MIM model would be appropriate for the data. The MIM model was initially used but consistently failed and defaulted to the CDE model. This suggests that the MIM model was insensitive to the observed physical nonequilibrium processes, while the CDE model was found to adequately describe the observed tracer breakthrough (Table 5, Fig. 9). To use the CDE at lower water contents, the retardation of the nonreactive tracers was fitted to values $<1$ to account for the early breakthrough that occurs due to media bypass and preferential flow (Gamerdinger and Kaplan, 2000). The fitted retardation factor for $\mathrm{Br}^{-}$and PIPES in the $60 \%$ saturated horizontal core was 0.57 and in the $40 \%$ saturated vertical core was 0.47 (Table 5). It was assumed that $\mathrm{Br}^{-}$and PIPES should have the same retardation factor and that any difference in the BTC was due to diffusion. Modeling of PFBA was achieved by disregarding the mass loss by microbial degradation. These findings suggest that the MIM model is insensitive to small but significant amounts of immobile water and demonstrates the importance of using multiple nonreactive tracers, rather than a single tracer, to quantify flow and transport in heterogeneous media.

\section{CONCLUSION}

Our results showed that small differences in the degree of saturation and heterogeneity of subsurface media could have a significant influence on flow and transport of contaminants in the vadose zone beneath the Hanford tank farms. Through the use of a multiple tracer technique and undisturbed core technology, we were able to quantify the influence of preferential flow and the formation of immobile water regimes during solute transport in the Hanford Formation. Enhanced advective dominated flow in the saturated horizontal cores (flow bedding parallel) vs. vertical cores (flow cross bedding) indicated that preferential flow along bedding may be preferred over flow across bedding forcing anisotropic lateral flow in the subsurface formation. Anisotropic flow occurs even at lower water contents, as was evident from the greater dispersion in the horizontal cores vs. the vertical core. Separation of multiple nonreactive tracers that had different rates of diffusion, early breakthrough of tracers, and a change in BTC symmetry from more asymmetric at slightly unsaturated conditions to increasingly symmetric at more unsaturated conditions indicated that preferential flow, media bypass, and the formation of immobile water regimes influenced transport at various water contents. Preferential flow in more conductive layers may result in accelerated transport of contaminants, while immobile water may act as a long-term source-sink for contamination in the vadose zone. Overall, our results indicated the importance of physical nonequilibrium in the Hanford vadose zone, which is due to a significant degree of heterogeneity between adjacent sediment layers in the Hanford Formation. Complex layering of coarse- to fine-grained sand and small-scale clay layers present in the Hanford Formation media can therefore be expected to influence contaminant mobility beneath the tank farms. It is uncertain how the heterogeneity of the Hanford Formation will affect flow and transport under significantly lower water contents. Research is underway to provide an improved conceptual understanding of flow and transport beneath the Hanford tank farms in an effort to aid in the prediction of contaminant movement and remediation of the site.

\section{ACKNOWLEDGMENTS}

This research was sponsored by the Hanford Site Integration Project Science and Technology Endeavor, Vadose Zone 
Technical Element, Richland, WA. The authors would like to thank Matt Fields, ORNL, for his work on the microbiological degradation of PFBA. Oak Ridge National Laboratory is managed by the University of Tennessee-Battelle, LLC, under contract DE-AC05-00OR22725 with the U.S. Department of Energy.

\section{REFERENCES}

Agnew, S.F., J. Boyer, R.A. Corbin, T.B. Duran, J.R. Fitzpatrick, K.A. Jurgensen, T.P. Ortiz, and B.L. Young. 1997. Hanford tank chemical and radionuclide inventories: HDW Model. LA-UR-963860, Rev. 4. Los Alamos National Laboratory, Los Alamos, NM.

Barry, D.A., and G. Sposito. 1988. Application of the convectiondispersion model to solute transport in finite soil columns. Soil Sci. Soc. Am. J. 52:3-9.

Becker, M.W., and A.M. Shapiro. 2000. Tracer transport in fractured crystalline rock: Evidence of nondiffusive breakthrough tailing. Water Resour. Res. 36:1677-1687.

Benson, C.F., and R.S. Bowman. 1994. Tri- and tetrafluorobenzoates as nonreactive tracers in soil and groundwater. Soil Sci. Soc. Am. J. 58:1123-1129.

Bjornstad, B.N. 1990. Geohydrology of the 218-W-5 burial ground, 200-west area, Hanford site. PNNL-7336. Pacific Northwest National Laboratory, Richland, WA.

Bond, W.J., and P.J. Wierenga. 1990. Immobile water during solute transport in unsaturated sand columns. Water Resour. Res. 26: 2475-2481.

Bowman, R.S. 1984. Evaluation of some new tracers for soil water studies. Soil Sci. Soc. Am. J. 48:987-993.

Bowman, R.S., and J.F. Gibbens. 1992. Difluorobenzoates as nonreactive tracers in soil and groundwater. Ground Water 30:8-14.

Brusseau, M.L., P.S.C. Rao, R.E. Jessup, and J.M. Davidson. 1989. Flow interruption: A method for investigating sorption nonequilibrium. J. Contam. Hydrol. 4:223-240.

Brusseau, M.L., Q. Hu, and R. Srivastava. 1997. Using flow interruption to identify factors causing nonideal contaminant transport. J. Contam. Hydrol. 24:205-219.

Carvalho, M.F., C.C.T. Alver, M.I.M. Ferreira, P. De Marco, and P.M.L. Castro. 2002. Isolation and initial characterization of a bacterial consortium able to mineralize fluorobenzene. Appl. Environ. Microbiol. 68:102-105.

Connelly, M.P., B.H. Ford, and J.U. Borghese. 1992. Hydrogeologic model for the 200 West groundwater area. WHC-SD-EN-T-014 (Rev. 0). Westinghouse Hanford Co., Richland, WA.

Dirkes, R.L., and R.W. Hanf. 1997. Hanford site environmental report for calendar year 1996. PNNL-11472. Pacific Northwest National Laboratory, Richland, WA.

Gamerdinger, A.P., and D.I. Kaplan. 2000. Application of continuousflow centrifugation method for solute transport in disturbed, unsaturated sediments and illustration of mobile-immobile water. Water Resour. Res. 36:1747-1755.

Glass, R.J., T.S. Steenhuis, and J.-Y. Parlange. 1988. Wetting front instability as a rapid and far-reaching hydrologic process in the vadose zone. J. Contam. Hydrol. 3:201-226.

Glass, R.J., T.S. Steenhuis, and J.-Y. Parlange. 1989. Mechanism for finger persistence in homogenous, unsaturated, porous media: Theory and verification. Soil Sci. 148:60-70.

Good, N.E., G.D. Winget, W. Winter, T.N. Connolly, S. Izawa, and R.M.M. Singh. 1966. Hydrogen ion buffers for biological research. Biochemistry 5:467-477.

Gwo, J.-P., R. O'Brien, and P.M. Jardine. 1998. Mass transfer in structured porous media: Embedding mesoscale structure and microscale hydrodynamics in a two-region model. J. Hydrol. (Amsterdam) 208:204-222.

Hartman, M.J., and P.E. Dresel. 1997. Hanford site groundwater monitoring for fiscal year 1996. PNNL-11470. Pacific Northwest National Laboratory, Richland, WA.

Hayduk, W., and H. Laudie. 1974. Prediction of diffusion coefficients for nonelectrolytes in dilute aqueous solutions. AIChE J. 20:611-615.

Hu, Q., and M.L. Brusseau. 1994. The effect of solute size on diffusivedispersive transport in porous media. J. Hydrol. (Amsterdam) 158: 305-317.
Hu, Q., and M.L. Brusseau. 1995. Effect of solute size in transport in structured, porous media. Water Resour. Res. 31:1637-1646.

Jardine, P.M., G.K. Jacobs, and G.V. Wilson. 1993. Unsaturated transport processes in undisturbed heterogeneous porous media: I. Inorganic contaminants. Soil Sci. Soc. Am. J. 57:945-953.

Jardine, P.M., R. O’Brien, G.V. Wilson, and J.-P. Gwo. 1998. Experimental techniques for confirming and quantifying physical nonequilibrium processes in soils. p. 243-271. In H.M. Selim and L. Ma (ed.) Physical nonequilibrium in soils: Modeling and application. Ann Arbor Press, Chelsea, MI.

Jardine, P.M., W.E. Sanford, J.P. Gwo, O.C. Reddy, D.S. Hicks, J.S. Riggs, and W.E. Bailey. 1999. Quantifying diffusive mass transfer in fractured shale bedrock. Water Resour. Res. 35:2015-2030.

Jardine, P.M., and D.L. Taylor. 1995. Kinetics and mechanisms of Co(II)EDTA oxidation by pyrolusite. Geochem. Cosmochim. Acta 59:4193-4203.

Jardine, P.M., G.V. Wilson, and R.J. Luxmoore. 1988. Modeling the transport of inorganic ions through undisturbed soil columns from two contrasting watersheds. Soil Sci. Soc. Am. J. 52:1252-1259.

Jardine, P.M., G.V. Wilson, R.J. Luxmoore, and J.P. Gwo. 2001. Conceptual model of vadose-zone transport in fractured weathered shales. p. 87-114. In Conceptual models of flow and transport in the fractured vadose zone. U.S. National Committee for Rock Mechanics, National Research Council. National Academy Press, Washington, DC

Jaynes, D.B. 1994. Evaluation of fluorobenzoate tracers in surface soils. Ground Water 32:532-538.

Klute, A. 1986. Water retention: Laboratory methods. p. 635-660. In A. Klute (ed.) Methods of soil analysis. Part 1. 2nd ed. Agron. Monogr. 9. ASA and SSSA, Madison, WI.

Koch, S., and H. Fluhler. 1993. Non-reactive solute transport with micropore diffusion in aggregated porous media determined by a flow-interruption method. J. Contam. Hydrol. 14:39-54.

Kung, K.-J.S., E.J. Kladivko, T.J. Gish, T.S. Steenhuis, G. Bubenzer, and C.S. Helling. 2000. Quantifying preferential flow by breakthrough of sequentially applied tracers: Silt loam soil. Soil Sci. Soc. Am. J. 64:1296-1304.

Langner, H.W., H.M. Gaber, J.M. Wraith, B. Huwe, and W. Inskeep. 1999. Preferential flow through intact soil cores: Effects of matric head. Soil Sci. Soc. Am. J. 63:1591-1598.

Lindsay, K.A. 1995. Miocene- to Pliocene-aged suprabasalt sediments of the Hanford site, south-central Washington. BHI-00184. Bechtel Hanford, Inc., Richland, WA.

Mayes, M.A., P.M. Jardine, I.L. Larsen, S.C. Brooks, and S.E. Fendorf. 2000. Multispecies transport of metal-EDTA complexes and chromate through undisturbed columns of weathered fractured saprolite. J. Contam. Hydrol. 45:243-265.

Mayes, M.A., P.M. Jardine, T.L. Mehlhorn, B.N. Bjornstad, J.L. Ladd, and J. Zachara. 2003. Transport of multiple tracers in variably saturated humid region structured soils and semi-arid region laminated sediments. J. Hydrol. 275(3-4):141-161.

McCarthy, J.F., K.M. Howard, and L.D. McKay. 2000. Effect of pH on sorption and transport of fluorobenzoic acid ground water tracers. J. Environ. Qual. 29:1806-1813.

Moline, G.R., R. Ketcham, and R.J. Toedte. 2001. Geologic controls on fracture-matrix exchange processes in fractured porous media: Results from a multi-tracer investigation. In B.H. Kueper et al. (ed.) Proc. Fractured Rock 2001 Conf., Toronto, ON, Canada. 25-28 Mar. 2001.

Murali, V., and L.A.G. Aylmore. 1980. No-flow equilibration and adsorption dynamics during ionic transport in soils. Nature 283: 467-469.

Newman, B.D., A.R. Campbell, and B.P. Wilcox. 1998. Lateral subsurface flow pathways in a semiarid ponderosa pine hillslope. Water Resour. Res. 34:3485-3496.

Oltmanns, R.H., R. Muller, M.K. Otto, and F. Lingens. 1989. Evidence for a new pathway in the bacterial degradation of 4-fluorobenzoate. Appl. Environ. Microbiol. 55:2499-2504.

Padilla, I.Y., T.-C. Yeh, and M.H. Conklin. 1999. The effect of water content on solute transport in unsaturated porous media. Water Resour. Res. 35:3303-3313.

Parker, J.C., and M.Th. van Genuchten. 1984a. Determining transport parameters from laboratory and field tracer experiments. Bull. 84-3. Virginia Agric. Exp. Stn., Blacksburg. 
Parker, J.C., and M.Th. van Genuchten. 1984b. Flux-averaged and volume-averaged concentrations in continuum approaches to solute transport. Water Resour. Res. 20:866-872.

Porro, I., and P.J. Wierenga. 1993. Transient and steady-state solute transport through a large unsaturated soil column. Ground Water 31:193-200.

Reedy, O.C., P.M. Jardine, G.V. Wilson, and H.M. Selim. 1996. Quantifying the diffusive mass transfer of nonreactive solutes in columns of fractured saprolite using flow interruption. Soil Sci. Soc. Am. J. 60:1376-1384.

Ritsema, C.J., J.W. Dekker, J.M.H. Hendrickx, and A.W. Hamming. 1993. Preferential flow mechanism in a water repellent sandy soil. Water Resour. Res. 29:2183-2193.

Ritsema, C.J., L.W. Dekker, J.L. Nieber, and T.S. Steenhuis. 1998. Modeling and field evidence of finger formation and finger recurrence in a water repellent sandy soil. Water Resour. Res. 34: $555-567$.

Roh, Y., M.A. Mayes, M.N. Pace, S.K. Choi, J. Chorover, D. Phillips, and P.M. Jardine. 2002. Mineralogical characterization of sediments at Hanford site, Washington. Clay Mineralogy Society Annual Meeting, Boulder, CO. 8-12 June 2002. Clay Mineral. Soc., Aurora, CO.
Schulin, R., P.J. Wierenga, H. Fluhler, and J. Leuenberger. 1987. Solute transport through a stony soil. Soil Sci. Soc. Am. J. 51:36-42.

Sililo, O.T.N., and J.H. Tellam. 2000. Fingering in unsaturated zone flow: A qualitative review with laboratory experiments on heterogeneous systems. Ground Water 38:864-871.

Song, B., N. Palleroni, and M.M. Haggblom. 2000. Isolation and characterization of diverse halobenzoate-degrading denitrifying bacteria from soils and sediments. Appl. Environ. Microbiol. 66: 3446-3453.

Tucker, W.A., and J.H. Nelken. 1982. Diffusion coefficients in air and water. p. 17-20. In W.J. Lyman, W.F. Reehl, and D.H. Rosenblatt. (ed.) Handbook of chemical property estimation methods: Environmental behaviour of organic compounds. McGraw-Hill, New York.

van Genuchten, M.Th., and P.J. Wierenga. 1986. Solute dispersion coefficients and retardation factors. p. 1025-1054. In A. Klute et al. (ed.) Methods of soil analysis. Part 1. 2nd ed. Agron. Monogr. 9. ASA and SSSA, Madison, WI.

van Genuchten, M.Th., F.J. Leij, and S.R. Yates. 1991. The RETC code for quantifying function of unsaturated soils. EPA/600/2-91/ 065. USDA-ARS, U.S. Salinity Lab., Riverside, CA. 